\title{
Budgetary Participation, Organizational Commitment, and Performance of Local Government Apparatuses
}

\author{
Bambang JATMIKOํㅜ, Titi LARAS², Azidatur ROHMAWATI ${ }^{3}$
}

Received: March 14, 2020 Revised: March 28, 2020 Accepted: June 09, 2020

\begin{abstract}
This study aims to get empirical evidence about the influence of budgetary participation and understanding of the accounting system on the performance of local government apparatus with organizational commitment as an intervening variable. The population in this study was structural apparatuses in the Regional Apparatus Organization (OPD) of Sleman Regency, Indonesia, which included offices and agencies with a total of 25 OPDs. 125 people were selected as sample by using purposive sampling based on specific criteria. Data were analyzed based on multiple regression and path analysis (Analysis Path) utilizing the SPSS program. The results of this study indicated that budgetary participation had no positive influence on organizational commitment; understanding of the accounting system had a positive effect on organizational commitment; organizational commitment did not have a positive effect on the performance of local government apparatuses; budgetary participation did not impact positively on the local government apparatuses performance; understanding of the accounting system positively effected the performance of local government apparatuses; participation in budgeting did not have a positive effect on the local government apparatuses performance through organizational commitment; while understanding the accounting system had a positive impact on the local government apparatuses performance through organizational commitment.
\end{abstract}

Keywords: Budgetary Participation, Performance, Organizational Commitment, Indonesia

JEL Classification Code: H11, H61, M41

\section{Introduction}

The Decree of the People's Consultative Assembly (MPR) Number 15 of 1998 concerning the Implementation of Regional Autonomy deals with Arrangement, Distribution, and Utilization of Equitable National Resources and Distribution of Central and Regional Finances within the Framework of the Unitary Republic of Indonesia. The MPR

${ }^{1}$ First Author and Corresponding Author. Lecturer, Business and Economic Faculty, Universitas Muhammadiyah Yogyakarta, Indonesia [Postal Address: Jl. Brawijaya, Tamantirto, Kec. Kasihan, Yogyakarta, 55183, Indonesia] Email: bambang.jatmiko@umy.ac.id ${ }^{2}$ Lecturer, Economic Faculty, Universitas Janabadra Yogyakarta, Indonesia

${ }^{3}$ Lecturer, Business and Economic Faculty, Universitas Muhammadiyah Yogyakarta, Indonesia

(c) Copyright: The Author(s)

This is an Open Access article distributed under the terms of the Creative Commons Attribution Non-Commercial License (http://Creativecommons.org/licenses/by-nc/4.0/) which permits unrestricted noncommercial use, distribution, and reproduction in any medium, provided the original work is properly cited.
Decree is the legal basis for the issuance of Law No. 22 of 1999, which is amended to Law No. 32 of 2004 concerning Regional Government, and Law No. 25 of 1999, which has been amended to Law No. 33 of 2004 concerning Financial Balance between the Central Government and Regional Governments. The implementation of regional government based on the Law has given birth to a new nuance, namely the change of authority of the government, which was initially centralized, to a decentralized government. This broadest shift in regional autonomy has influenced several crucial aspects of the financial sector. With these changes, it is expected that the budget produced by the region can be used in building, developing, and in preparing budgets in each local area that is in accordance with the community needs.

The budget is one of the most crucial elements of the regional government (Pemda) to build the foundation and hopes of Indonesian citizens. The budget is used as a coordinating, communication, control, and evaluation tool by regional governments to fulfill their obligations for a 
certain period in financial form. The budget is an estimated performance statement to be realized during a specific period expressed in financial time (Mardiasmo, 2002). Budgeting in public-sector organizations is an essential activity because it associates with the determination of the funds' allocation process for each activity and program. The government needs to be capable of realizing a clean government and prioritizing the principles of equality, effectiveness, and efficiency in providing good services to stakeholders (the public).

There are two approaches in the budget preparation process, namely, the top-down approach and the bottomup approach. The bottom-up approach is also often called participative budgeting. Participatory budget research studies on the performance of local government apparatuses are often questioned because they provide varying results. For example, research conducted by Sardjito and Muthaher (2008), Saefulloh (2013), and Safitri and Agusti (2014) showed that there was an influence of budgetary participation on the local government apparatuses performance. Likewise, the results of research conducted by Ferdiani and Rohman (2012), and Nurcahyani (2010) showed a similar result: there was a positive and significant effect between budgetary participation and managerial performance. However, research by Nufianto (2012) and Puri (2015) confirmed that budgetary participation did not have a positive effect on the performance of regional work units. It supports research conducted by Nazaruddin and Setyawan (2016), showing that budgetary participation had no positive and significant impact on improving the performance of local government apparatuses. It indicates the existence of other variables that influenced it.

Regional Financial Accounting Systems, in its understanding, must be considered; it is used in order to provide information in presenting reliable financial reports so that users of the report easily understand them; then, it must be done by employees who are experts in the field of regional financial accounting systems. The regional financial accounting system, according to the Decree of the Minister of Home Affairs No. 29 of 2002, is "the accounting system, which includes the process of recording, classifying, interpreting, summarizing transactions or financial events as well as financial reporting in the framework of implementing the Regional Revenue and Expenditures Budget (APBD), implemented under generally accepted accounting principles, and carried out manually or using applications." Regional financial management is closely related to the financial accounting system, where regional financial management can present reliable financial reports. Research conducted by Saefulloh (2013) showed that financial accounting systems affected local governments' performance. Further, research conducted by Tuasikal (2007), Ramandei (2009), Sukmana and Anggarsari (2009) showed a similar thing that apparatus performance of the Regional Work Unit had a very close relationship with the level of understanding of the regional financial accounting system. It contrasts with research conducted by Atmaja (2011), which showed that there was no influence between the regional financial accounting system on the regional work unit's performance.

To carry out programs or activities that are in line with the organization's vision and mission with the hope of achieving organizational goals, each government apparatus must have organizational commitment. Commitment is needed as a basis for doing an excellent job in the organization. High commitment will usually make individuals in publicsector organizations (local government apparatuses) try to perform well to accomplish the goals of the organization. In addition, with the high commitment, the government apparatus will have a better understanding of the goals of the organization, strive to stay in the organization and to emphasize the interests of the organization, rather than their interests. Sardjito and Muthaher (2008), and Wulandari and Mutmainah (2011), indicate that the high level of commitment that existed in a regional government apparatus could improve performance.

This research is a replication of Saefulloh (2013) by using two independent variables, namely, budgetary participation and regional financial accounting systems conducted in the Subang district government. Therefore, the present study was conducted in the Sleman Regency Government by adding one intervening variable, namely, the organizational commitment variable. Based on the above background problems, the budgetary participation and understanding of the accounting system of the Sleman Regency Government apparatus were still less than optimal. Supported by organizational commitment owned by each Sleman Regency government apparatus, it is expected to be able to realize the ideals of reform; thus, the governance processes can run with well. The following is a table of the Accumulation of Regional Revenues and Expenditures in the Regional Organization of Sleman Regency in 2011-2015:

Based on Table 1, the data are reflected in the regional revenue budget with its realization and the expenditure budget with its realization. When viewed from the regional revenue budget and its realization, the regional income budget, which had been set, always had a lower number than its realization. Then, the regional budget and the regional budget realization showed that the regional expenditure always had lower realization compared to the stipulated budget. Based on these data from 2011 to 2015, the Sleman Regency Regional Revenue and Expenditure Budget spent more expenditure budget than revenue budget. It proved that the ability of the Regional Apparatus Organization was still very minimal. 
Table 1: Realization of Regional Revenue and Expenditures Budget (APBD) of Sleman Regency for 2011-2015 (In Millions)

\begin{tabular}{|c|c|c|c|c|}
\hline Year & $\begin{array}{c}\text { Budget Revenue } \\
(\mathbf{R p})\end{array}$ & $\begin{array}{c}\text { Realization of Revenue } \\
(\mathbf{R p})\end{array}$ & $\begin{array}{c}\text { Expenditures } \\
(\mathbf{R p})\end{array}$ & $\begin{array}{c}\text { Realization of } \\
\text { Expenditures (Rp) }\end{array}$ \\
\hline 2011 & 1.272 .583 & 1.311 .473 & 1.376 .859 & 1.278 .055 \\
\hline 2012 & 1.475 .128 & 1.589 .722 & 1.595 .739 & 1.421 .401 \\
\hline 2013 & 1.768 .438 & 1.899 .525 & 1.946 .380 & 1.693 .528 \\
\hline 2014 & 1.969 .264 & 2.076 .820 & 2.288 .645 & 1.896 .477 \\
\hline 2015 & 2.262 .230 & 2.294 .622 & 2.770 .682 & 2.328 .751 \\
\hline
\end{tabular}

Source: BAPPEDA Sleman Regency website

\section{Literature Review and Hypothesis Development}

According to Mardiasmo (2002), in the Public Sector Accounting book, the definition of the budget is as follows: "Budget is a statement about the estimated performance to be achieved during a certain period stated in financial time, while budgeting is a process or method for preparing a budget." The research by Saefulloh (2013) examined the effect of participation in budgeting and regional financial accounting systems on the local governments' performance in Subang District government offices. The results showed that participation in budgeting and regional financial accounting systems had a positive effect on the performance of local governments in the Subang District government service. Budgetary Participation is a process that involves subordinates, both individuals and groups, who are directly in it and have influence in the preparation, and the implementation, as well as the performance, will be evaluated based on the achievement of the budget Sardjito and Muthaher (2008).

The research by Sardjito and Muthaher (2008) explored the effect of budgetary participation on the local government apparatuses performance using organizational culture and organizational commitment as a moderating variable. The results showed that participation in budgeting had a significant impact on the performance of local government apparatuses. The variables of organizational culture and organizational commitment also had a significant influence in moderating the correlation between budgetary participation and the local government apparatus's performance. The research by Ferdiani and Rohman (2012) examined the effect of budgetary participation on the managerial performance of the employees of the Central Java provincial secretariat: organizational commitment and perception of innovation were intervening variables. The results showed that budgetary participation and the managerial performance had a significant influence; budgetary participation and organizational commitment had a significant influence; organizational commitment and the managerial performance had a significant effect; budgetary participation and perception of innovation had a significant influence; and there was a significant influence on the perception of innovation and managerial performance.

The Decree of the Minister of Home Affairs No. 29/2002 article 70 first paragraph, concerning guidelines for the management, accountability, and supervision of regional finances as well as the procedures for preparing the Regional Revenue and Expenditure Budget (APBD), the implementation of regional financial administration, and compilation of the Regional Expenditure Budget, reads: "Regional Financial Accounting (SAKD) is an accounting system that includes the process of recording, classifying, interpreting, summarizing transactions of financial events and financial reporting in the context of implementing the Regional Revenue and Expenditure Budget (APBD), carried out under accounting principles." The local government performance, according to Tuasikal (2007), is a description of the level of the achievement of a program, an activity, or implementation of a policy in realizing the objectives, goals, mission, and vision of the organization as outlined in the formulation of strategic scheme in an organization.

The research by Ramandei (2009) examined the effect of understanding the accounting system and regional financial management on the performance of regional work units with internal control as an intervening variable. The results showed that the understanding of the accounting system and financial management influenced the performance of the Regional Apparatus Work Unit (SKPD) through internal control. Whereas, the regional financial accounting system and financial management did not affect the Regional Apparatus Work Unit (SKPD) performance. The research by Nurcahyani (2010) investigated the effect of budgetary participation on managerial performance through organizational commitment and perception of innovation as an intervening variable. The results indicated that budgetary participation affected managerial performance, while budgetary participation did not affect managerial performance through organizational commitment, and budgetary participation did not influence 
managerial performance through the perception of innovation. Mardiasmo (2002) also stated the role of performance indicators for the government is to help to clarify the goals of the organization, evaluate the final targets produced, show performance standards, show effectiveness, and help determine activities that have the best cost-effectiveness to achieve the target.

Organizational commitment is defined as the level of trust and acceptance of work towards the organization's goals and has a desire to remain in the organization (Safitri \& Agusti, 2014). In this view, employees who are highly committed will prioritize the interests of the organization rather than personal or group interests. Organizational commitment is needed as an indicator of employee performance. If the employee has a high commitment, it is expected to show maximum performance. Further, the employees who join the organization are required to commit themselves. With the commitments given, it is expected that employee performance will improve. Nowadays, companies or public-sector organizations have used commitments as considerations in raising their position. Employees have different behavior depending on the commitment they have in an organization. If employees who have a low commitment do the work forcefully, the achievement of goals will become less than the maximum. Conversely, if employees have a high commitment, they will strive to achieve organizational goals. To strengthen the hypothesis, the researchers also referred to several previous studies that can strengthen the theory, empirical, and logical thinking:

\subsection{The Effect of Budgetary Participation on Organizational Commitment}

Organizational commitment is an attitude that reflects where the organization members voice their apprehension for the organization and the success and continuous progress (Akbar, Udin, Wahyudi, \& Djastuti, 2018; Djastuti, Rahardjo, Irviana, \& Udin, 2019; Safitri \& Agusti, 2014; Udin, 2020). It shows that employees are ready and able to start a continuous attempt for organizational success. Lower-level employees have more accurate information because they know the field conditions than the top-level employees. Lower-level employees will try to provide sufficient information to top-level employees in carrying out program and unit activities. In addition, the commitment of employees in the organization can be used as a means to maintain organization survival.

Commitment is not only seen from the actual work of each individual, but also from the values that apply in the organization. Ferdiani and Rohman (2012) emphasized that participation in budgeting requires the involvement of more employees in the preparation process. With this involvement, employees will better understand the budget structure and be able to solve problems that might arise so that it can be said that a strong commitment to the organization will grow. High commitment to the organization will make employees complete tasks well and be more responsible for their duties. Also, if employees with low commitment do the work forcefully, the achievement of goals will be less than the maximum, while if employees have a high commitment, they will strive to achieve organizational goals. It is in line with research by Safitri and Agusti (2014), Nurcahyani (2010), and Ferdiani and Rohman (2012), which stated that budgetary participation impacted on organizational commitment. Thus,

$\mathrm{H}_{1}$ : Budgetary participation has a positive effect on organizational commitment.

\subsection{The Effect of Understanding of the Accounting System on Organizational Commitment}

The accounting system is a crucial part of the spectrum of overall control mechanisms that are employed to measure, motivate, and sanction organization employees' and managers' actions (Ramandei, 2009). According to Tuasikal (2007), the regional financial accounting system is one of the containers that are considered relevant in linking information that is used as a coordinating tool to oversee government activities attached to the Regional Revenue and Expenditure Budget (APBD). The Minister of Domestic Decree No. 29 of 2002 article (70) contains regional financial accounting system understanding, concerning the process of recording, managing, summarizing financial transactions, and reporting the results of financial management in the Regional Revenue and Expenditure Budget (APBD) implemented under generally accepted accounting principles.

Public-sector organizations, especially local governments, are required to have an understanding in the field of regional financial accounting systems to improve the local governments' performance (Tuasikal, 2007). It indicates that the accounting system understanding can encourage the improvement of the public-service performance of local government work units and in decision making. Displaying a good performance, especially in the public sector, requires the involvement of more employees in the budgeting process. With this involvement, employees will better understand the budget structure and be able to solve problems that will arise and in decision making. Thus, it will grow a strong commitment to the organization. High commitment to the organization will make employees more responsible for the task. Thus,

$\mathrm{H}_{2}$ : Understanding of the accounting system has a positive effect on organizational commitment. 


\subsection{The Effect of Organizational Commitment on the Performance of Local Government Apparatus}

Weiner in Wulandari and Mutmainah (2011) stated that organizational commitment is support from within individuals to be able to do something in sustaining organizational success and prioritizing group interests rather than individual interests. Support from each individual is used to influence the level of organizational success that contributes to budget preparation and improves managerial performance. Organizational commitment becomes a benchmark to determine the extent to which local government apparatuses favor a particular organization and to preserve the organization membership (Doan, Nguyen, \& Nguyen, 2020; Nguyen \& Tu, 2020; Do, Nguyen, Nguyen, Ha, \& Le, 2020).

High commitment makes individuals more concerned with the interests of the organization rather than personal interests, still trying to become an organization in order to become better in improving higher performance as well. Low organizational commitment will make individuals act in their interests. Research by Ferdiani and Rohman (2012) stated that there was a positive influence between organizational commitment and managerial performance of regional secretariat employees. In line with Sardjito and Muthaher (2008), Wulandari and Mutmainah (2011) stated that there was a positive and significant influence between organizational commitment and the performance of local government apparatuses. However, it is different from the research by Kharisma (2015), and Safitri and Agusti (2014), which stated that organizational commitment did not influence the performance of local government apparatuses. Thus,

$\mathrm{H}_{3}$ : Organizational commitment has a positive effect on the performance of local government.

\subsection{The Effect of Budgetary Participation on Performance of Local Government Apparatuses}

Participation in budgeting is an approach that can largely advance the performance, which can ultimately increase the effectiveness of an organization. Brownell and Mcinnes (1986) in Agusti (2012) assert that high budgetary participation increases managerial performance. According to Sardjito and Muthaher (2008), the higher the budget participation, the more the regional government apparatus performance will increase. In line with research conducted by Ferdiani and Rohman (2012), Agusti (2012), Saefulloh (2013), and Safitri and Agusti (2014), it showed that budgetary participation had a positive impact on the local government apparatuses performance. Similar results conducted by Ferdiani and Rohman (2012), which indicated that budgetary participation had a positive impact on managerial performance. However, it differs from research conducted by Nazaruddin and Setyawan (2016), Nurfianto (2012), and Puri (2015), which showed that there could not be a positive influence between budgeting participation on the performance of local government apparatuses. Thus,

$\mathrm{H}_{4}$ : Participation in budgeting has a positive effect on the performance of local government.

\subsection{The Effect of Understanding of the Accounting System on the Local Government Apparatus Performance}

The accounting system is a process of recording, classifying, interpreting, summarizing transactions or financial events, as well as, reporting their budgets in the context of implementing the Regional Revenue and Expenditure Budget (APBD), carried out under generally accepted accounting principles established under regional regulations. Paul (1997) and Zimmerman (2000) in Tuasikal (2007) asserted that in making decisions relating to public services, local governments must have adequate understanding in the area of regional finance. An increasing understanding of the accounting system causes an increase in the performance of government organizations by encouraging decision making and controlling financial activities by managers to be better. Mardiasmo (2002) argues that the Regional Government's performance will be achieved if the partial implementation of the Regional Financial Accounting System; it can provide a strong impetus for the local governments' performance to be achieved.

Based on the theory above, it shows that the better the regional financial accounting system, the performance of the government apparatus will increase. The regional financial accounting system includes available financial information assessing the allocation of resources. The more complete the financial information needed, the easier it is for employees to perform their performance. With the existence of an excellent financial accounting system in an organization, it is required to be able to give convenience to the regional government apparatuses in preparing financial reports. Research conducted by Tuasikal (2007), Nufianto (2012), Saefulloh (2013), and Sukmana and Anggarsari (2009) showed that there was an influence between the accounting system understanding and the local governments' performance. It revealed that the regional government apparatus performance had a very close relationship with the level of understanding of the regional financial accounting system. This research is different from research conducted by Ramandei (2009) and Atmaja (2011), which showed that understanding the accounting system did not have a positive influence on regional work units. Thus, 
$\mathrm{H}_{5}$ : Understanding the accounting system has a positive effect on the performance of local government.

\subsection{The Effect of Budgetary Participation on Performance of Local Government Apparatus mediated by Organizational Commitment}

Participation in budgeting requires the involvement of more employees in the preparation process. With this involvement, employees will better understand the budget structure and be able to solve problems that may arise. Thus, it will grow a strong commitment to the organization. High commitment to the organization will make employees more responsible for the task and display better performance. Employees who are involved in the budgeting process will have a higher commitment to the organization. With high commitment, employees will show better performance.

However, on the contrary, if the level of commitment is low, then the employee will be forced to do his work so that resulting in a decrease in the performance. Ferdiani and Rohman (2012) used organizational commitment as an intervening variable in research on budgetary participation and managerial performance. The results of the study stated that there was a positive relationship between budgetary participation and organizational commitment and between organizational commitment to managerial performance. Whereas, the research by Nurcahyani (2010) stated that there was no impact between preparation participation and managerial performance through organizational commitment. Thus,

$\mathrm{H}_{6}$ : Budgeting participation has a positive effect on the performance of local government through organizational commitment as an intervening variable.

\subsection{The Effect of Understanding of the Accounting System on the Performance of Local Government Apparatuses through Organizational Commitment as an Intervening variable}

Decree of the Minister of Home Affairs No. 29/2002 article 70 paragraph (1), concerning the process of recording, managing, summarizing financial transactions, and reporting the results of financial management in the State Budget, shall be carried out under generally accepted accounting principles. Louise (1999) in Tuasikal (2007) emphasized that publicsector organizations, especially local governments, must have an adequate understanding of regional financial accounting systems that can improve the local governments' performance, including work units. It indicates that the understanding of the regional financial accounting system can encourage the improvement of the public-service performance of the regional apparatus organizations and in decision making.

In displaying excellent performance, especially in the public sector, it requires the involvement of many employees in the budgeting process. With this involvement, employees will better understand the budget structure and be able to solve problems that will arise and in decision- making. Thus, it will grow a strong commitment to the organization. High commitment to the organization will make employees more responsible for the task. Research from Ferdiani and Rohman (2012) confirmed that organizational commitment had a positive impact on managerial performance. In line with it, research conducted by Sardjito and Muthaher (2008) stated that there was a significant influence between organizational commitment and the local government apparatus's performance. High commitment makes individuals more concerned with the organization rather than personal interests; they will be responsible for the task and display better performance. Thus,

$\mathrm{H}_{7}$ : Understanding of the accounting system has a positive effect on the performance of local government through organizational commitment as an intervening variable.

\section{Research Methods}

The object in this research was the Regional Apparatus Organization (OPD) in Sleman Regency, whereas the subjects were the head of the section, head of the division, heads of sub-division, and head of sub-division of the Sleman Regency Office and Agency. The data employed in this study were primary data. Primary data were one of the data collection techniques directly using a questionnaire. It was by submitting questionnaires directly to respondents in each unit in the Regional Organization of Sleman Regency. The primary data collection method employed in this study was to ask questions related to the variables used in this study, namely, budgeting participation, understanding of the accounting system, the performance of local government apparatuses, and organizational commitment. The reason for using primary data was because this method considers the novelty and ease of obtaining information.

The sampling method in this study was to utilize the purposive sampling method. Purposive sampling, according to Sugiyono (2018), is a sampling technique where samples can be obtained by setting specific criteria. These criteria were the Sleman Regency Regional Government Agencies occupying positions as section heads, division heads, section heads, subdivision heads, and subdivision heads from the Sleman Regency Government Office and Agency. The reason why choosing the position of section head, division head, section head, subdivision head, and subdivision head, as these criteria were because the respondent already had 
experience in the budget preparation process for which he/ she was responsible.

The research method employed the survey method, meaning that the primary data collection method was by giving written questions with a questionnaire. The questionnaire was given to respondents directly by submitting a research permit, a request for filling out the questionnaire, and a research questionnaire. The questionnaire was taken back in accordance with the time promised by the respondents. The variables utilized in this study were measured using a Likert scale model, a scale based on the sum of respondents' attitudes in answering questions related to the concept or variable indicators being calculated (Puri, 2015). In this case, the respondents were asked to agree or disagree with each question with the following score descriptions: 5 (strongly agree), 4 (agree), 3 (neutral), 2 (disagree), and 1 (strongly disagree). The analysis technique employed was path analysis. According to Ghozali (2006), path analysis is a multiple linear regression analysis extension, or path analysis is the regression analysis utilizing approximate causality relationships between variables (causal models) that have been predetermined based on theory.

\section{Results}

\subsection{Determination Coefficient Test Results}

The determination coefficient testing was conducted by scrutinizing how much each adjusted R Square bears on each independent variable, which showed how much the independent variable could justify the dependent variable. The adjusted $R$ Square value of 0.226 indicates that the independent variables PPA and PSA were only capable of explaining the intervening KO variable by $22.60 \%$, while the remaining $77.40 \%$ was influenced by other variables that were not researched. The adjusted $\mathrm{R}$ square value of 0.020 signifies that the independent variables KO, PPA, and PSA were only capable of explaining the dependent variable of local government apparatus performance by $2 \%$, while the remaining $98 \%$ was influenced by variables others that were not researched.

\subsection{T-Test Results}

The t-test was employed to see the impact of partially independent variables on the dependent variable so that the results for each hypothesis would be known (see Table 2). Table 2 shows that, for the results of multiple regressions for substructure 1, the significance value for the PSA variable was 0,000 , where the PSA variable $<$ alpha 0.05 . It means that the independent variable PSA affected the intervening KO variable. Whereas, the PPA variable was 0607 , where the PPA variable $>$ alpha 0.05 . It indicates that the independent variable PPA did not affect the intervening $\mathrm{KO}$ variable.

Table 3 shows that, for the multiple regression results for substructure 2, it can be seen that the significance value for the PSA variable is 0.043 , for the PPA variable is 0.729 , and the $\mathrm{KO}$ variable is 0.068 . PSA variable had a significance level $<$ alpha 0.05 , which indicates that the independent variable PSA influenced the dependent variable K. Meanwhile, the PPA and KO had a significance level $>$ alpha 0.05 , which means that PPA and $\mathrm{KO}$ did not affect the $\mathrm{K}$ variable.

\subsection{Path Analysis Results}

Figure 1 presents a complete picture of the sub-structure along with path analysis.

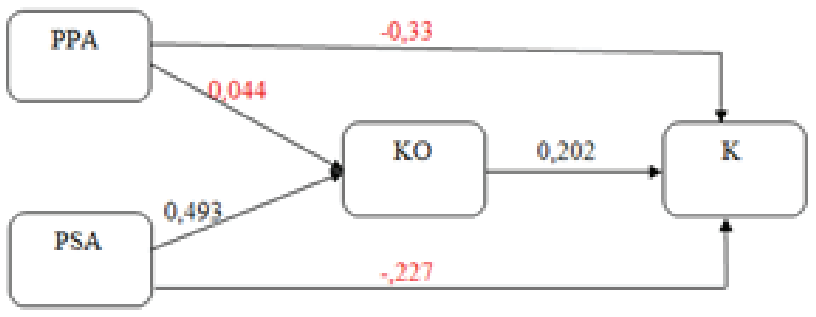

Figure 1. Path Analysis Results

\subsubsection{Hypothesis 1}

Table 3 shows that budgetary participation (PPA) has a significance value of $0.607>$ alpha 0.05 , with a negative

Table 2: T-Test Results of Substructure Regression 1

\begin{tabular}{|l|c|c|c|c|c|c|}
\hline \multirow{2}{*}{ Model } & \multicolumn{2}{|c|}{ Unstandardized Coefficients } & $\begin{array}{c}\text { Standardized } \\
\text { Coefficients }\end{array}$ & \multirow{2}{*}{ Sig. } \\
\cline { 3 - 7 } \multicolumn{2}{|c|}{} & B & Std. Error & B & & \\
\hline \multirow{3}{*}{1} & (Constant) & 6.321 & 5.708 & & 1.107 & .271 \\
\cline { 2 - 7 } & PSA & .883 & .153 & .493 & 5.764 & .000 \\
\cline { 2 - 7 } & PPA & .060 & .116 & .044 & .516 & .607 \\
\hline \multicolumn{7}{|l|}{ a. Dependent Variable: KO } \\
\hline
\end{tabular}


Table 3: T-Test Results of Substructure Regression 2

\begin{tabular}{|c|c|c|c|c|c|c|}
\hline & \multirow{2}{*}{ Model } & \multicolumn{2}{|c|}{ Unstandardized Coefficients } & \multirow{2}{*}{$\begin{array}{c}\begin{array}{c}\text { Standardized } \\
\text { Coefficients }\end{array} \\
\text { B } \\
\end{array}$} & \multirow{2}{*}{$T$} & \multirow{2}{*}{ Sig. } \\
\hline & & B & Std. Error & & & \\
\hline \multirow{4}{*}{1} & (Constant) & 71.446 & 8.353 & & 8.553 & .000 \\
\hline & PSA & -.525 & .256 & -.227 & -2.054 & .043 \\
\hline & PPA & -.058 & 168 & -.033 & -.347 & .729 \\
\hline & $\mathrm{KO}$ & .262 & .142 & .202 & 1.844 & .068 \\
\hline
\end{tabular}

$\beta$ coefficient direction of 0.044 . It means that budgetary participation had a negative impact on organizational commitment. Thus, Hypothesis 1 stating that budgetary participation had a positive impact on organizational commitment, was rejected.

\subsubsection{Hypothesis 2}

Based on Table 3, it shows that the understanding of the accounting system (PSA) has a significance value of $0,000<$ alpha 0.05 , with a positive $\beta$ coefficient direction of 0.493 . It indicates that the higher the PSA, the higher the K. It can be concluded that the understanding of the accounting system had a positive impact on organizational commitment. Thus, Hypothesis 2, which stated that the understanding of the accounting system had a positive influence on organizational commitment, was otherwise accepted.

\subsubsection{Hypothesis 3}

Table 3 shows that the organizational commitment (KO) significance value is $0.068>$ alpha 0.05 by having a positive $\beta$ coefficient direction of 0.202 . Even though the direction of the coefficient $\beta$ was positive, due to its significance level $>$ alpha 0.05 , the organizational commitment did not influence the local government apparatus performance. Thus, Hypothesis 3 was rejected.

\subsubsection{Hypothesis 4}

Based on Table 3, it reveals that budgetary participation (PPA) has a significance value of $0.729>$ alpha 0.05 , with the direction of the negative $\beta$ coefficient of -0.33 . It indicated that budgetary participation had a negative impact on the local government apparatus performance. Thus, Hypothesis 4 was rejected.

\subsubsection{Hypothesis 5}

Based on Table 3, it signifies that the understanding of the accounting system (PSA) has a significance value of $0.043<$ alpha 0.05 , with the direction of the $\beta$ coefficient of -0.227 . It implies that the accounting system understanding variable had a negative and significant direction on the dependent variable of the regional government apparatus performance. Also, it indicates that the understanding of the accounting system had a significant negative impact on the performance of the regional government apparatus. Thus, Hypothesis 5 was accepted.

\subsubsection{Hypothesis 6}

Budgeting participation (PPA) directly and indirectly affected the local government apparatus performance through organizational commitment (KO). Thus, to find out which path was right, then the path analysis was carried out, as follows (see Figure 2):

$$
\begin{array}{ll}
\left(A_{1} \times A_{2}\right) & \geq A_{3}{ }^{2} \\
(0,044 \times 0,202) & \geq-0,33^{2} \\
0,009 & \leq 0,109
\end{array}
$$

The comparison of the multiplication between standardized coefficient from PPA to KO (A1) with standardized coefficient from KO to K (A2) was $0.009<$ standardize coefficient of PPA to K (A3) of 0.109. The most appropriate path to the influence of PPA on $\mathrm{K}$ is the direct path. Therefore, Hypothesis 6 was rejected.

\subsubsection{Hypothesis 7:}

The t-test was to verify the understanding of the accounting system (PSA) effect on the local government apparatus (K) performance. It is known that PSA had a direct effect on organizational commitment (KO), and $\mathrm{KO}$ had no effect on K. Whereas, PSA had a direct effect on K, which can be seen in the path, as follows (see Figure 3):

Consequently, it can be concluded that Hypothesis 7, which stated that the understanding of the accounting system on the local government apparatuses performance through organizational commitment, was rejected. 


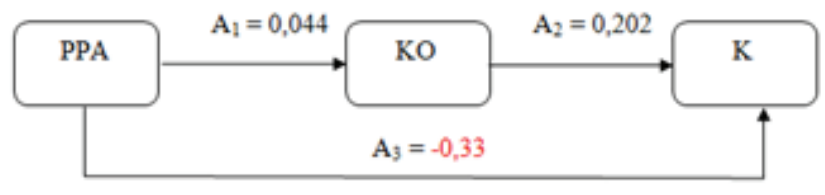

Figure 2. Results of Path Analysis 1

a

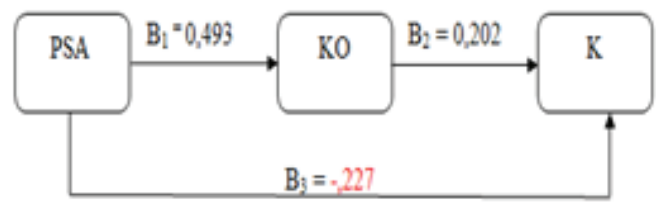

Figure 3. Path Analysis Results 2

\section{Discussion}

\subsection{On Organizational Commitment}

\subsubsection{The Effect of Budgetary Participation}

The results of testing the first hypothesis indicate that budgetary participation had no positive effect on organizational commitment. It shows that employee participation in the budgeting process was still low; basically, budgeting requires the involvement of more employees in the preparation process. With this involvement, employees will understand the structure of the budget and can solve problems that may arise, so that a strong commitment to the organization will grow. High commitment to the organization will make employees more responsible for the task. Allegedly, it happened due to a lack of communication in the preparation of the budget.

Also, only some employees participate in preparing the budget. The employees did not understand how to prepare a budget, or they did not have the ability in accordance with their fields. Besides, if employees with low commitment did the work forcefully, the achievement of the goals became less than optimal. The results of the current study disagree with the results of research conducted by Nurcahyani (2010), Ferdiani and Rohman (2012), and Safitri and Agusti (2014), which stated that budgetary participation had a positive impact on organizational commitment.

\subsubsection{The Influence of Understanding the Accounting System}

The results of the second hypothesis testing revealed that understanding the accounting system had a positive effect on organizational commitment. Louise (1999) in Tuasikal (2007) emphasized that public-sector organizations, especially local governments, must have an adequate understanding of regional financial accounting systems that can improve the performance of regional governments, including work units. It indicates that the understanding of the regional financial accounting system can encourage the improvement of the public-service performance of local government work units and in decision making.

Whereas, in showing a good performance in the public sector, it requires the involvement of more employees in the budgeting process. With this involvement, employees will better understand the budget structure and be able to solve problems that might arise in decision making. Therefore, a strong commitment to the organization will grow. High commitment to the organization will make employees more responsible for their duties.

\subsection{On the Local Government Apparatuses Performance}

\subsubsection{The Effect of Organizational Commitment}

The results of testing the third hypothesis indicated that organizational commitment did not have a positive impact on the performance of local government apparatuses. It was supported by the phenomenon that occurred in Sleman Regency, namely budget absorption, which was still relatively low in some OPDs in Sleman Regency. It was because the commitment of the local government apparatus was still low. In other words, there were still programs/ activities or development that had not been implemented by the local government apparatus in carrying out their government. Therefore, there were still funds that could not be used properly and had not been maximized.

The current study results do not support the results of research conducted by Sardjito and Muthaher (2008) and Wulandari and Mutmainah (2011), which stated that there was a positive and significant influence between organizational commitment and the local government apparatus performance. Besides, research conducted by Ferdiani and Rohman (2012) stated that organizational commitment had a positive impact on the managerial performance of regional secretariat employees. However, it is consistent with the results of research conducted by Kharisma (2015), and Safitri and Agusti (2014), which stated that organizational commitment did not affect the local government apparatus performance.

\subsubsection{The Effect of Budgetary Participation}

The fourth hypothesis testing results indicated that budgetary participation did not have a positive impact on the performance of the local government apparatus. It was because the decisions taken by the head of the Regional Apparatus Organization (OPD) did not yet reflect the participation of lower-level employees or the community. 
Although participation in Sleman Regency was quite high, decision making still depended on the Head of the Regional Apparatus Organization (OPD). Thus, it can be said that participation in budgeting did not affect the decisions taken by the Head of the Regional Apparatus Organization (OPD).

The present study results are different from the results of research conducted by Sardjito and Muthaher (2008), Ferdiani and Rohman (2012), Agusti (2012), Saefulloh (2013), and Safitri and Agusti (2014), which stated that budgetary participation had a positive impact on the regional government apparatus performance. Likewise, the results of research conducted by Ferdiani and Rohman (2012) showed similar results that there was a positive and significant impact between budgeting participation on managerial performance. However, it is coherent with the results of research conducted by Nazaruddin and Setyawan (2016), Nufianto (2012), and Puri (2015), which stated that participation in the preparation of the budget did not have a positive impact on the local government apparatuses performance.

\subsubsection{The Influence of Understanding of the Accounting System}

The results of testing the fifth hypothesis revealed that understanding the accounting system had a positive impact on the local government apparatus's performance. It showed that in making OPD decisions in Sleman Regency that related to public services, the local government must have an adequate understanding of the area of regional finance. An increasing understanding of the accounting system causes an increase in the performance of government organizations by encouraging decision making and better controlling the financial activities of managers.

The results of this study support the research conducted by Tuasikal (2007), Nufianto (2012), Saefulloh (2013), and Sukmana and Anggarsari (2009), which proved the influence of understanding the accounting system on the local government apparatus performance. It does not agree with research conducted by Ramandei (2009) and Atmaja (2011), which showed that understanding the regional financial accounting system did not have a positive impact on the regional work unit's performance.

\subsection{On the Local Government Apparatuses Performance through Organizational Commitment}

\subsubsection{The Impact of Budgetary Participation}

The results of the sixth hypothesis testing indicated that budgetary participation had no positive impact on the local government apparatus performance through organizational commitment. The first hypothesis stated that there was no positive correlation between budgetary participation and organizational commitment. The analysis showed that there was no correlation between the two variables. Thus, the hypothesis stating that budget participation did not have a relationship to organizational commitment could not be accepted. The low level of employee participation in budgeting would result in the low commitment of employees to other employees in the organization. The third hypothesis stated that there was no relationship between organizational commitment and the local government apparatus's performance.

From the analysis that has been carried out, it is evident that there was indeed no relationship between organizational commitment and the local government apparatus's performance. Through the results of the analysis, it can be concluded that the hypothesis, which stated that organizational commitment and the local government apparatus performance did not have a positive and significant relationship, could not be accepted. The higher the commitment the employee has towards the organization, the higher the performance that can be performed by the employee.

However, vice versa, if the level of commitment is low, then the employee will be forced to do his/her work so that the performance demonstrated will decrease. The results of this study conflict the results of research conducted by Ferdiani and Rohman (2012), which proved that budgeting participation influenced managerial performance through organizational commitment. However, it agrees with the results of research conducted by Nurcahyani (2010), which stated that budgetary participation did not affect managerial performance through organizational commitment.

\subsubsection{The Influence of Understanding of the Accounting System}

The results of the seventh hypothesis testing indicated that budgetary participation had a positive impact on the performance of local government apparatuses through organizational commitment. The second hypothesis stated that there was a positive correlation between understanding the accounting system and organizational commitment.

The analysis revealed that there was a relationship between the two variables. Thus, the hypothesis stating that understanding the accounting system had a relationship to organizational commitment could be accepted. It indicates that the understanding of the regional financial accounting system can lead to an increase in the performance of publicservice organizations in the regional apparatus and decision making. In showing good performance, especially in the public sector, it requires the involvement of many employees in the budget preparation process. With this involvement, employees will better understand the budget structure and be able to solve problems that will arise and in making decisions. A strong commitment to the organization will grow. 


\section{Conclusion}

Based on the results of testing, processing, and analysis that had been done, the following conclusions could be drawn:

-Based on the research, the results of budgetary participation did not have a positive impact on the commitment of the Regional Government Organizations of the Sleman Regency government.

-Understanding of the accounting system had a positive impact on the commitment of the Regional Government Organizations of the Sleman Regency government.

-Organizational commitment does not have a positive impact on the regional government apparatus performance of the Regional Government Organizations of the Sleman Regency government.

-Budgeting participation did not have a positive and significant impact on the regional government apparatus performance of the Regional Government Organizations of the Sleman Regency government.

-Understanding of the accounting system had a positive impact on the regional government apparatus performance of the Regional Government Organizations of the Sleman Regency government.

-In the preparation of the budget, participation did not have a positive impact on the local government apparatuses performance through the commitment of the Regional Government Organizations of the Sleman Regency government.

-Understanding the accounting system had a positive impact on the local government apparatus performance through the commitment of the Regional Government Organizations of the Sleman Regency government.

This research is expected to be considered by Local Government Agencies, especially the Sleman Regency Government, in the government process. The following should be noted:

-The low participation of local government apparatuses in the budget preparation caused work programs in the Regional Government of Sleman Regency not to run optimally (maximum).

-Budgets were made as a means of control and evaluation used by local governments to carry out their obligations in specific periods in activities or programs. It avoids the possibility that might arise in carrying out activities or programs, so that organizational goals can be achieved.

-With the high absenteeism of employees, reporting the results of the activities of each organization were heavily delayed. Also, it caused the lack of understanding by employees, so the reports produced were not in accordance with the provisions. Besides, it made programs or activities that had been prepared from the beginning delayed and abandoned. Thus, it caused development in the Sleman District to become obstructed.
-There was a lack of communication of the Regional Apparatus Organization in responding to complaints and community needs and the use of funds that were not conveyed to stakeholders. It made it difficult for the stakeholders to access information, so that decision-making was difficult to make. Therefore, it is expected that the Sleman Regency Government can improve the quality of public services.

\section{References}

Agusti, R. (2012). The effect of budgetary participation on the performance of local government apparatus is moderated by the variable decentralization and organizational culture (Case study in Bengkalis District Government). Journal of Economics, 20(3), 1-15. doi: https://je.ejournal.unri.ac.id/index.php/JE/ article/view/1173

Akbar, A. B., Udin, Wahyudi, S., \& Djastuti, I. (2018). Spiritual Leadership and Employee Performance: Mediating Role of Organizational Commitment in Indonesian Public University. Journal of Engineering and Applied Sciences, 13(12), 4344-4352. https://medwelljournals.com/ abstract/?doi=jeasci.2018.4344.4352

Atmaja, K. T. (2011). The Influence of Understanding of Accounting Systems, Regional Financial Management and Reporting Systems on the Performance of Regional Work Units (Studies in Regencies and Cities in Yogyakarta Special Province). (Thesis), Universitas Muhammadiyah Yogyakarta, Indonesia.

Brownell, P., \& McInnes, M. (1986). Budgetary Participation, Motivation, and Managerial Performance. The Accounting Review, 61(4), 587-600.

Djastuti, I., Rahardjo, S., Irviana, L., \& Udin, U. (2019). Fun at work and employee performance: the roles of job satisfaction and organizational commitment in manufacturing companies. WSEAS Transactions on Business and Economics, 16, 153-162.

Do, D. T., Nguyen, T. H., Nguyen, T. H. N., Ha, H. H., \& Le, T. T. (2020). The Influence of Leadership Style on Accountants' Commitment with Enterprise: An Empirical Study on Vietnamese FDI Firms. Journal of Asian Finance, Economics and Business, 7(3), 235-243. https://doi.org/10.13106/ jafeb.2020.vol7.no3.235

Doan, T. T. T., Nguyen, L. C. T., \& Nguyen, T. D. N. (2020). Emotional Intelligence and Project Success: The Roles of Transformational Leadership and Organizational Commitment. Journal of Asian Finance, Economics and Business, 7(3), 223233. https://doi.org/10.13106/jafeb.2020.vol7.no3.223

Ferdiani, D., \& Rohman, A. (2012). The effect of budgetary participation on managerial performance of the employees of the Central Java provincial secretariat: organizational commitment and perception of innovation as intervening variables. (Thesis (Undergraduate)), Fakultas Ekonomika dan Bisnis, Universitas Indonesia.

Ghozali, I. (2006). Multivariate Analysis Application with SPSS Program (4th Edition). Semarang: Badan Penerbit Universitas Diponegoro. 
Kharisma. (2015). The influence of organizational culture, organizational commitment, competence on the performance of local government officials through good governance as a moderating variable (Empirical Study at the Regional Secretariat in the City Government of Wonosobo). (Thesis), Universitas Muhammadiyah Yogyakarta, Indonesia.

Kloot, L. (1999). Performance Meansurement and Accounting in Victorian Local Government. The International Journal of Publik Sector Management, 12(7), 565-584. https://doi. org/10.1108/09513559910308039

Mardiasmo. (2002). Public sector accounting. Yogyakarta: Andi.

Nazaruddin, I., \& Setyawan, H. (2016). The Effect of Budgetary Participation on Performance of Local Government Officials with Organizational Culture, Organizational Commitment, Motivation, Decentralization, and Job Relevant Information as Moderation Variables. Journal of Accounting and Investment, 12(2), 197-207. doi: https://journal.umy.ac.id/index.php/ai/ article/view/684

Nguyen, T. H., \& Tu, V. B. (2020). Social Responsibility, Organizational Commitment, and Organizational Performance: Food Processing Enterprises in the Mekong River Delta. Journal of Asian Finance, Economics and Business, 7(2), 309316. https://doi.org/10.13106/jafeb.2020.vol7.no2.309

Nufianto, A. (2012). The Influence of Understanding of the Accounting System, Regional Financial Management and Budgeting Participation on the Performance of Regional Work Units (Study in Gunungkidul Regency in Yogyakarta Special Province). (Thesis), Universitas Muhammadiyah Yogyakarta, Indonesia.

Nurcahyani, K. (2010). Effect of Budget Participation on Managerial Performance Through Organizational Commitment and Innovation Perception as Intervening Variables. (Thesis), Universitas Diponegoro, Indonesia.

Puri, E. P. G. (2015). The Influence of Budgetary Participation, Leadership Style, and Motivation Participation on the Performance of Regional Work Units (Empirical Study on SKPD Purworejo Regency). (Thesis), Universitas Muhammadiyah Yogyakarta, Indonesia.
Ramandei, P. (2009). Influence of Characteristics of Budget Targets and Internal Control Systems on the Managerial Performance of Local Government Officials (Empirical Study on Regional Work Units of Jayapura City). Diponegoro University.

Saefulloh, I. (2013). The Influence of Budgetary Participation and Regional Financial Accounting Systems on the Performance of Local Government in the Subang Regency Government. (Thesis), Universitas Komputer Indonesia, Indonesia.

Safitri, D., \& Agusti, R. (2014). The effect of budgetary participation on the performance of local government officials through organizational commitment and perception of innovation as an intervening variable (empirical study on the regional work unit of Siak district). Jom Fekon, 1(2), 1-15. doi: https://www. academia.edu/download/50709327/3955-7745-1-SM.pdf

Sardjito, B., \& Muthaher, O. (2008). Effects of Budgetary Participation on Performance of Local Government Officials: Culture and Organizational Commitment as Moderating Variables. Journal of Economics and Business, 2(1), 37-49.

Sugiyono. (2018). Quantitative, Qualitative, and R\&D Research Models. Bandung: Alfabeta.

Sukmana, W., \& Anggarsari, L. (2009). The Influence of Internal Oversight and the Implementation of the Regional Financial Accounting System on the Performance of Local Governments. Journal of Accountinga, 4(1).

Tuasikal, A. (2007). The influence of understanding of the accounting system, regional financial management on the performance of local government work units (Study in Central Maluku District in Maluku Province). Journal of Public Sector Accounting and Finance, 8(1), 1466-1483.

Udin, U. (2020). Transformational Leadership and Organizational Commitment: A Review of Literature. Journal of Research And Opinion, 7(2), 2623-2626. https://doi.org/10.15520/jro.v7i2.49

Wulandari, N. E., \& Mutmainah, S. (2011). The Effect of Budgetary Participation on Performance of Local Government Officials: Job Satisfaction and Organizational Commitment as Moderating Variables (Empirical Study of Demak District Government). (Undergraduate thesis), Universitas Diponegoro, Indonesia. 